Clim. Past, 9, 2003-2011, 2013

www.clim-past.net/9/2003/2013/

doi:10.5194/cp-9-2003-2013

(C) Author(s) 2013. CC Attribution 3.0 License.

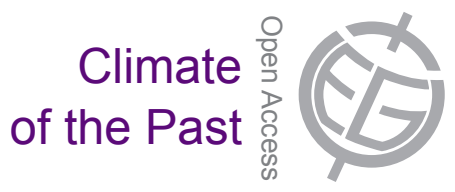

\title{
On the Milankovitch sensitivity of the Quaternary deep-sea record
}

\author{
W. H. Berger ${ }^{1, *}$ \\ ${ }^{1}$ Geosciences Research Division, Scripps Institution of Oceanography, University of California, San Diego, USA \\ *Invited contribution by W. H. Berger, recipient of the Milutin Milankovic Medal 2012. \\ Correspondence to: W. H. Berger (wberger@ucsd.edu)
}

Received: 11 January 2013 - Published in Clim. Past Discuss.: 4 March 2013

Revised: 19 June 2013 - Accepted: 15 July 2013 - Published: 21 August 2013

\begin{abstract}
The response of the climate system to external forcing (that is, global warming) has become an item of prime interest, especially with respect to the rate of melting of land-based ice masses. The deep-sea record of ice-age climate change has been useful in assessing the sensitivity of the climate system to a different type of forcing; that is, to orbital forcing, which is well known for the last several million years. The expectation is that the response to one type of forcing will yield information about the likely response to other types of forcing. When comparing response and orbital forcing, one finds that sensitivity to this type of forcing varies greatly through time, evidently in dependence on the state of the system and the associated readiness of the system for change. The changing stability of ice masses is here presumed to be the chief underlying cause for the changing state of the system. A buildup of vulnerable ice masses within the latest Tertiary, when going into the ice ages, is thus here conjectured to cause a stepwise increase of climate variability since the early Pliocene.
\end{abstract}

\section{Introduction}

The ice-age record of deep-sea sediments demonstrates changing sensitivity of the climate of the last $2 \mathrm{Myr}$ to "Milankovitch forcing" (MF in what follows). This is hardly in doubt any more. The pioneer studies of Hays et al. (1976) and the milestone articles in A. Berger et al. (1984) established that MF is present in the record, and can be used for tuning (i.e., for detailed age assignment). Also, by the mid1980s it was shown that MF history can drive geophysical models able to generate an ice-mass history that closely mimics the real world (Pollard, 1984). These findings also opened the possibility of assessing the stability of the planetary orbits in the solar system, which are ultimately responsible for MF history through geologic time (A. Berger et al., 1992). In short, Milankovitch theory has become central to all discussion of the long-term climate history of the ice ages and beyond, and not only for the deep-sea record (e.g., Fischer et al., 1985; A. Berger et al., 1989; Einsele et al., 1991; Schwarzacher, 1993; EPICA Community Members, 2004).

It is true that the problems arising when linking orbital forcing to the observed climate response are complex. The ice-age climate system does not produce a random walk but is constrained to fluctuations between rather well defined boundaries while tending to avoid a central position, facts that imply the presence of both positive and negative feedbacks, with sign and strength of feedback dependent on the state of the system. Many or most of these problems have been aired and discussed following the pioneer studies mentioned. They are a matter of much discussion still (Ruddiman et al., 1989; Liu and Chao, 1998; W. Berger, 1999, 2008; Ridgwell et al., 1999; Elkibbi and Rial, 2001; Leuschner and Sirocko, 2003; Raymo and Nisancioglu, 2003; Paillard and Parrenin, 2004; A. Berger et al., 2005; Huybers and Wunsch, 2005; Maslin and Ridgwell, 2005; Claussen et al., 2006; Raymo et al., 2006; Meyers et al., 2008; Lisiecki, 2010; Huybers, 2007, 2009, 2011; Holden et al., 2011; Nie, 2011). Here I do not propose to address the various issues arising in this discussion. Instead, my intent is to highlight certain implications of traditional Milankovitch theory, which may not have received the attention that they deserve.

Of special interest in the ongoing discussions are obvious changes in the ice-age climate's sensitivity to forcing through time, which express themselves as changes in the response to various portions of the spectrum in the orbital forcing. These 
changes illustrate that there are a host of different feedbacks within the climate system, some apparently linked to certain portions of the spectrum. The central idea in Milankovitch theory, albedo feedback in high latitudes, no longer holds the monopolistic position it was once accorded by many adherents of the theory. Processes in the tropics and feedbacks associated with monsoon activity have to be considered as well. Nevertheless, faced with the ensuing complexity, it makes sense to return to the simple approach implicit in the original theory. The main reason for doing so is that the original theory produces usable results, and is indeed widely employed by geologists.

In the present essay, the emphasis is on a simple comparison of high-latitude summer forcing (as calculated by A. Berger and Loutre, 1991) and the oxygen isotope record on the deep-sea floor (as compiled by Zachos et al., 2001, and by Lisiecki and Raymo, 2005). What emerges from this comparison is that there is no single valid definition of "Milankovitch sensitivity" as the response of the climate system depends entirely on the contemporary state of the system and its readiness to move in one direction or another.

For good reasons, then, what may be called the Milankovitch sensitivity of the climate system (MS in what follows, defined as the ratio of the standardized amplitudes of "response" to those of the "forcing," that is, of the derivative of the oxygen isotope record to the Milankovitch-type insolation as given by A. Berger and Loutre, 1991) remains elusive, even in the Quaternary, with its strong Milankovitch affiliations. Superficially, within the late Quaternary, the main reason for the difficulty of relating MF to the climate response is the problem of the $100 \mathrm{kyr}$ cycle. The " $100 \mathrm{kyr}$ problem", much discussed by the pioneers (Imbrie and Imbrie, 1980; Imbrie et al., 1984, 1992, 1993) and since, reflects the fact that the dominant climate cycle of the time span studied by Milankovitch (the last $650 \mathrm{kyr}$; that is, the "Milankovitch chron" of W. Berger and Wefer, 1992) has a period near $100 \mathrm{kyr}$. There is, however, no readily identifiable MF that could drive climate variation on this cycle. Many solutions to this conundrum have been proposed. Perhaps the most radical proposition rejects Milankovitch theory altogether and invokes the cyclic variation of the inclination of the average orbital plane of the planets in our solar system (Muller and McDonald, 2000). Other possible solutions, staying within Milankovitch theory, postulate long-term internal oscillation that is captured by eccentricity-related MF, notably varying precession, presumably with the help of stochastic forcing, or else elements of orbital forcing combined with a chaotic response.

Even if the $100 \mathrm{kyr}$ problem were solved, however, the difficulty of defining MS would remain. It certainly would continue to exist for the time before the Milankovitch chron, a time when there were no $100 \mathrm{kyr}$ cycles. The MS changes considerably both within the $100 \mathrm{kyr}$ cycles (as exemplified by the presence of terminations; that is, threshold events) and it changes noticeably on longer timescales as well, presum- ably largely owing to a strong link to the size of the ice mass present in the Northern Hemisphere and its stability (Dolan et al., 2011). In addition, the MS is strongly influenced, presumably, by tectonic processes and associated erosion rates (Roe and Baker, 2007; Tomkin and Roe, 2007; A. Berger et al., 2008; Brocklehurst, 2008; Champagnac et al., 2012).

Thus, the attempt to obtain a quantitative measure of Milankovitch sensitivity must fail. However, it is worth exploring whether there are ways to track this elusive parameter semi-quantitatively, mainly for the purpose of obtaining a record of stability. MS did change greatly through geologic time, presumably initially because of the buildup of northern ice (identified by Milankovitch as the crucial element in the ice-age climate system; Milankovitch, 1930), and at a later stage in consequence of the increasing vulnerability of ice masses to a rise in sea level. This particular element of instability presumably was caused by the erosion of fjords and basins that allowed deep penetration of seawater to below existing ice masses, as well as the expansion of ice, which moved ice margins into waters offshore.

The implication of a changing MS for using the ice ages as a source of lessons for recent and present climate change is to greatly increase uncertainty. The chief lesson of the present exercise indeed is that forcing is just one element of the problem; the response depends largely on the state of the system. Presumably, the best analog periods for today's situation would be those for which the MS pattern is similar to the present one. If the MS cannot be measured, however (as seems to be the case), its patterns cannot be compared in detail from one period to another. Substituting MF for MS (for example, by taking Stage 11 as a good analog for the Holocene; A. Berger and Loutre, 2003) may work, but moves the argument into the realm of geologic time, with other problems arising, notably long-term secular changes in feedback mechanisms from erosion and from the buildup of major coral reef structures within the Pleistocene.

\section{System response to Milankovitch forcing}

The evidence that orbital forcing (Milankovitch forcing) is involved in guiding ice-age fluctuations is largely based on spectral analysis of the type pioneered by Hays et al. (1976). This type of analysis compares the spectra of the orbital variation with those obtained from climate records and finds that there are similarities. Similarities, in fact, can be greatly increased if one compares the spectrum of orbitally controlled insolation at a given location (here, the latitude of $65^{\circ} \mathrm{N}$ in July; A. Berger and Loutre, 1991) with the first derivative of the oxygen isotope record for benthic foraminifers (Zachos et al., 2001, and Lisiecki and Raymo, 2005, combined and re-dated; W. Berger, 2011). The derivative of the record emphasizes short-term fluctuations in the $10 \mathrm{kyr}$ scale in preference to long-term changes in the $100 \mathrm{kyr}$ scale, an effect that is favorable for the comparison (Fig. 1). Also, using the 


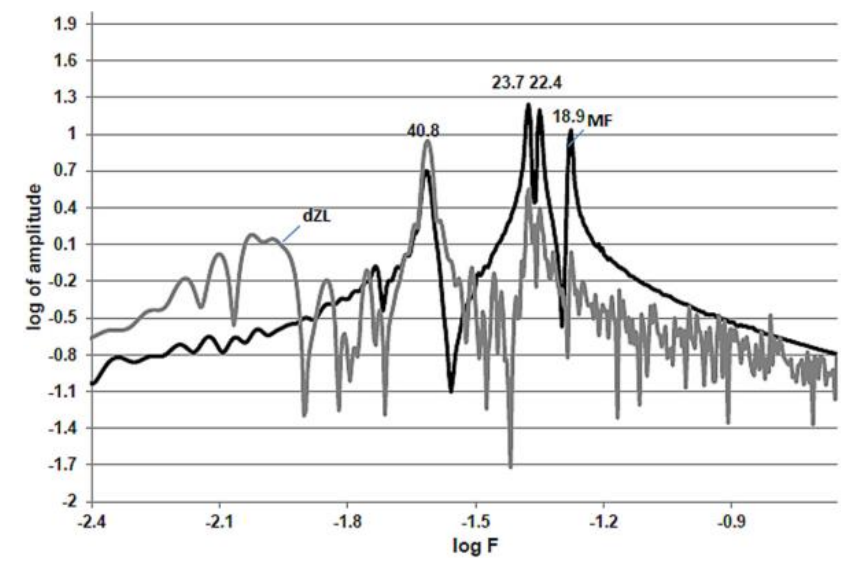

Fig. 1. Comparison of the spectra of orbital variations (as reflected in the insolation at $65^{\circ} \mathrm{N}$, in July; A. Berger and Loutre, 1991) and in the oxygen isotope record of benthic foraminifers, for the last million years (Table A1 in W. Berger, 2011).

derivative of the proxy seems to adjust the phase of forcing and response in a favorable manner.

The comparison of the two spectra (forcing and proxy derivative) documents that obliquity and precession effects are well represented in the record, but that there is additional information in the climate record, near $100 \mathrm{kyr}(\log$ $F \sim 2$ ), that has no equivalency in the forcing. This is the well known but poorly understood $100 \mathrm{kyr}$ problem that was already mentioned. Finding matching lines within the spectra of orbital forcing and the climate record supports the Milankovitch theory (as pointed out by Hays et al., 1976, and many since). However, it does not uniquely identify the translation mechanism that converts the forcing to climate change. In fact, the $100 \mathrm{kyr}$ problem raises the possibility that no such mechanism exists for portions of the spectrum. Clearly, it is the response of the climate system to forcing that we are interested in when discussing sensitivity within the framework of ice-age history. With the translation mechanism unidentified, such sensitivity remains a somewhat fuzzy concept. The fundamental insight of Milankovitch (1930) was the realization that the response of the system most likely originates in high latitudes of the Northern Hemisphere, and that the ice masses there are particularly vulnerable to melting within warm northern summers (Fig. 1). This insight led him to postulate forcing in terms of summer insolation in high northern latitudes.

Although aware of positive feedback from albedo (hence the choice of a crucial latitude in the far north, where snow can persist through the summer), Milankovitch assumed that the response to forcing would be predictable and well behaved. This assumption allowed him to use MF as a template for the reconstruction of conditions in the ice ages (most prominently in his graph published by Köppen and Wegener, in 1924). The proposition that ice growth and ice decay display the type of behavior postulated by Milankovitch

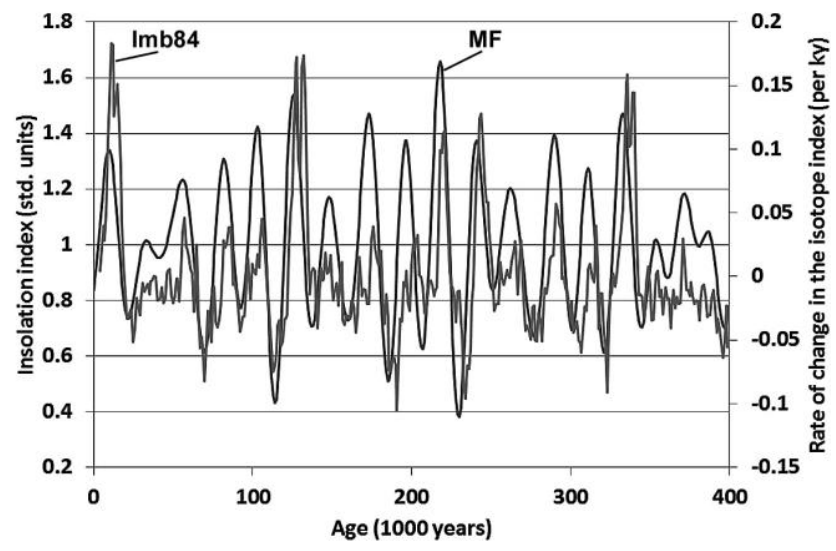

Fig. 2. Comparison of the derivative of the SPECMAP template (Imbrie et al., 1984) with MF as given in A. Berger and Loutre (1991). All values are standardized (by linear transform). The rate of change in the oxygen isotope record (secondary $y$ axis) can be read as meters of sea-level change per decade, approximately.

can be tested. It fails the test. The test here applied consists in finding the linear windowed correlation of two series, MF and the derivative of the oxygen isotope record in deep-sea sediments, after precise matching of MF with that proxy derivative.

As suggested by the comparison of spectra (Fig. 1), the matching (or "Milankovitch tuning") is best done between MF and the derivative of the proxy record; that is, the oxygen isotope stratigraphy of benthic or planktonic foraminifers. After all, Milankovitch theory refers to change in response to orbitally controlled insolation. A match of the high-latitude summer insolation series to environmental conditions (such as ice mass) is actually not a correct representation of the theory (even if it was done by Milankovitch himself).

The most widely used proxy record tuned to Milankovitch forcing and available for decades is the stacked record published by Imbrie et al. (1984) and commonly referred to as the "SPECMAP" template (here: "Imb84"). Its numerical derivative is readily made in a spreadsheet. Comparison with MF shows the good fit expected from tuning (MF here is taken as the series calculated by A. Berger and Loutre (1991); that is, the insolation for July at $65^{\circ} \mathrm{N}$.). The precise phase between MF and response is unknown, as is the variability of that phase. The good fit between MF and proxy derivative seen represents an assumption of zero phase shift and zero variability of phase between the two series considered, a conjecture that simplifies the issue but has no inherent heuristic value.

It is immediately obvious from inspecting Fig. 2 that the fit is in the timing, but that the magnitude of the response is not closely linked to the magnitude of the MF (the mean is set to unity, and one standard deviation to 0.25 ). Evidently the sensitivity of the system to forcing changes through time, 


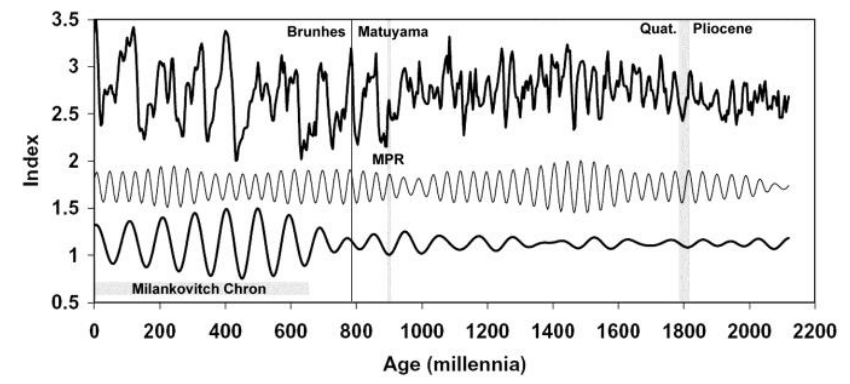

Fig. 3. Oxygen isotope record of ODP (Ocean Drilling Program) Site 806: extraction of ca. $40 \mathrm{kyr}$ and ca. $100 \mathrm{kyr}$ cycles by Fourier analysis. Adapted from W. Berger and Wefer (1992).

reflecting the changing state of the system. That this is the case has been well known for several decades. A major change in sensitivity during the Pleistocene manifests itself, for example, in the Mid-Pleistocene climate shift, when the system started to strongly respond to precession (and hence indirectly to eccentricity) in addition to the changing tilt of Earth's axis (Pisias and Moore, 1981; Ruddiman et al., 1989). The appearance of a strong $100 \mathrm{kyr}$ cycle some $650 \mathrm{kyr}$ ago (W. Berger and Wefer, 1992; Mudelsee and Stattegger, 1997; Mudelsee and Schulz, 1997) is another major change in climate response (Fig. 3). In fact, the apparent striking sensitivity of the climate system to forcing associated with the ca. $100 \mathrm{kyr}$ cycle has provided a rich field for investigation and conjecture since the 1990s (Imbrie et al., 1993; W. Berger, 1999; A. Berger et al., 2005; Maslin and Ridgwell, 2005; Ganopolski and Calov, 2011; Nie, 2011). In the case of this long-term cycle internal oscillation and threshold response to both nonlinear orbital forcing and stochastic forcing have to be considered, in addition to orbital effects (Tziperman et al., 2006). It is interesting that the somewhat shorter obliquity cycles persisted throughout the Quaternary, despite the remarkable changes in the mixture of climate cycles seen in the appearance of the $100 \mathrm{kyr}$ cycle (Fig. 3).

\section{3 "Deaf zones"}

Traditionally, the assessment of MS relies on globally relevant proxy records thought to be Milankovitch driven, commonly the oxygen isotope record of either benthic or planktonic foraminifers. Remarkably, the difference between the two types of proxy records is not important in the context (Fig. 4). This suggests that both records reflect the dominant parameter of climate change (ice mass) or else that other parameters that matter (such as local temperature) are highly correlated to the primary one (that is, to ice mass). Given the observed similarities, I shall analyze the compilations of benthic proxy records in what follows, confident that they represent global signals rather than local ones. Therefore, the implication is that any effects of changing bottom-water properties on the proxy record can be neglected, since they run

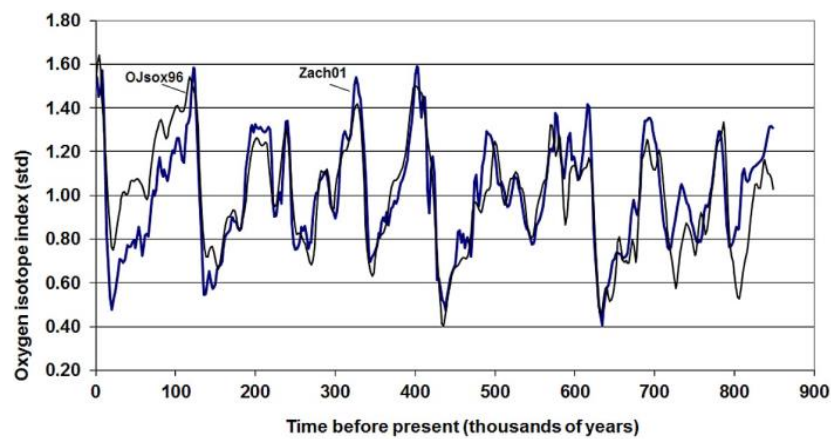

Fig. 4. Comparison of standardized oxygen isotope series from deep-sea sediments, one based on planktonic foraminifers ( $G$. sacculifer), ODP Site 806, Ontong Java Plateau (W. Berger et al., 1993); the other based on $1 \mathrm{kyr}$ interpolation of a compilation of benthic values by Zachos et al. (2001), on a global scale.

parallel to the main response factor and do not impact the global signal.

The compilations are based on tuned records. Thus, a good fit to Milankovitch forcing can be taken to be built in. Nevertheless, I have combined the compilations of Zachos et al. (2001) and of Lisiecki and Raymo (2005) and re-tuned the resulting series to Milankovitch forcing (high-latitude summer insolation; A. Berger and Loutre, 1991) by matching the derivative of the stacked record (Table A1 in W. Berger, 2011) to MF, as indicated in Fig. 2. Both series employed ("forcing" and "response") comprise the last million years in $1 \mathrm{kyr}$ intervals. The procedure should yield maximum values for MS. To get a general assessment of the behavior of MS over large time intervals I have used windowed linear correlation, as mentioned. The procedure answers the question of how well proxy series and MF are correlated along a sliding window after making the described match. To establish the effects of window size on the outcome, I chose $12 \mathrm{kyr}, 25 \mathrm{kyr}$, $50 \mathrm{kyr}$ (Fig. 5) and $100 \mathrm{kyr}$ (not shown). The larger windows, in essence, represent summations of the shorter ones.

Whatever the window size chosen, there are some striking stretches of very low correlation, suggesting very little influence of MF on the climate record in spite of the presence of ice-age cycles. I have referred to such time spans as "deaf zones" elsewhere (W. Berger, 2011, 2013). However, the term "deaf," while describing the situation correctly as far as a lack of agreement between forcing and climate record, may be misleading. Some of the "deafness" may result from a lack of power in the forcing; that is, from insufficient power of MF to move the system, and not from an inherent lack of sensitivity of the system to outside influence (Fig. 5, bottom panel). If true, a difficult question arises: to what degree does "sufficiency" in the MF depend on the state of the system, and, therefore, does "sufficiency" change through time? Changes in sufficiency of the forcing presumably may affect the practice of Milankovitch tuning through geologic time, generating periods of high resolution 


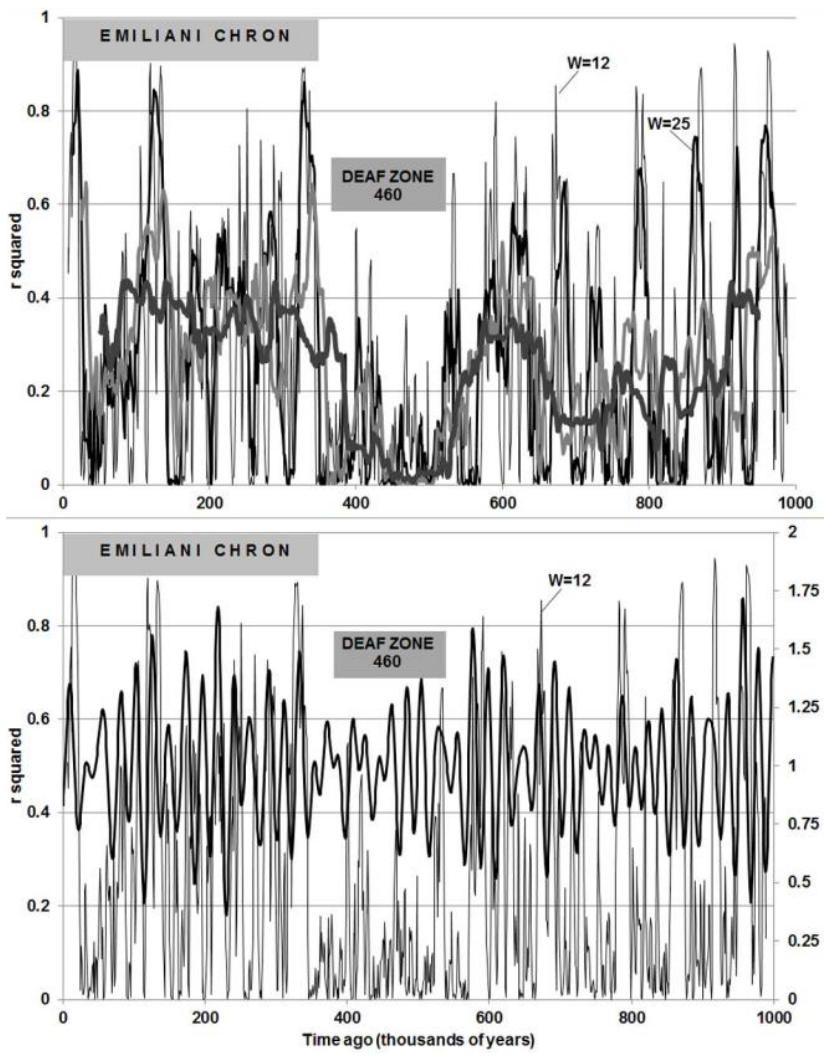

Fig. 5. Evidence for a lack of MS in climate change ("deaf zone") centered on $460 \mathrm{kyr}$, in windowed correlation of MF and a proxy series based on compilations of Zachos et al. (2001) and Lisiecki and Raymo (2005), combined, interpolated, and re-tuned to Milankovitch forcing (W. Berger, 2011; Table A1). The "deaf zone" includes Stage 12. Its end defines the beginning of the "Emiliani chron," the time span studied by Emiliani (1955) and recognized as rich in climate cycles. $W=12$, window width is $12 \mathrm{kyr}$. Heavy gray line (top graph), window width is $50 \mathrm{kyr}$. Black line (bottom graph): MF (from A. Berger and Loutre, 1991).

but also periods with greater uncertainty in age assignments. Such tuning is now widely applied, following the success of Shackleton et al. (1990) in correctly dating sediments of Pleistocene age and of various authors in finding verifiable ages for sediments considerably older than that (e.g., Hilgen et al., 1995; Shackleton et al., 1995; Liebrand et al., 2011). In any case, the term "deaf" refers strictly to Milankovitch forcing, so it might usefully be changed to "M-deaf."

\section{4 "Terminations"}

The response of the climate system to Milankovitch forcing is observed to be at maximum strength during deglaciation events; that is, the relatively brief periods when large ice masses in the Northern Hemisphere disappear entirely, and sea level rises accordingly. The periodic switch within the system from buildup of ice to its rapid demise gives rise to asymmetric cycles, as noted first by Broecker and van Donk (1970), who also coined the label "termination" for the large-scale melting of glacial ice masses. That the rapid decay of ice indicates instability within the system was emphasized by Hughes (1987), among others.

Questions surrounding the stability of ice masses both in Greenland and in Antarctica have become of urgent importance in recent years, given that global warming is inexorably proceeding (e.g., Jansen et al., 2007; Holden et al., 2011). It seems obvious, from comparing MF with the timing of the onset of terminations (Fig. 6) that MF acts as a trigger in these circumstances rather than as a driver; that is, we are dealing with threshold phenomena when looking at fast melting. Threshold events may not be amenable to sensitivity analysis. Presumably, patterns observed arise in response to the contemporary conditions of the system. I suspect that conditions are uniquely defined by the amount of ice mass present and its age (W. Berger, 1997; Paul and Berger, 1997).

The implication for the urgent question arising in present circumstances (stability of ice masses in the face of global warming) is that the stability of large polar ice masses varies through time and is a product of preceding history. The masses either are stable or unstable, presumably largely dependent on their internal temperature and on the presence of backstops such as shelf ice. The sensitivity of the system to external forcing is not a given quantity but freely adjusts to the environment, which is itself defined by contingencies. There is one very clear message from the record, however. It is that there is plenty of inertia in the system. History suggests that once large ice masses start deteriorating they will continue to do so for more than a thousand years, presumably largely reflecting internal system feedback rather than only external forcing. If so, this would imply that a disintegration of large ice masses, once started, is irreversible on a timescale of centuries. To what degree such disintegration reflects the participation of the ocean in climate system processes (e.g., Broecker and Denton, 1989) is an interesting question that remains to be investigated. Simple physical principles suggest that disintegrating ice heats up from fast motion and breaks up, thus admitting lubricating water to the base of the ice. Essentially, we are facing the complexities posed by landslides of a very special nature. In addition, ice masses that terminate within the sea are vulnerable to a rise in sea level, as well as to tsunamis. These vulnerabilities introduce stochastic forcing from earthquakes and high frequency astronomical forcing from the tides. Evidently, both types of forcing are of interest in the context of threshold events. Stochastic forcing presumably is most effective whenever a system is ready to move on its own anyway.

\section{Agitation through time}

A highly variable climate system may be said to have a high level of "agitation"; that is, its various elements change 

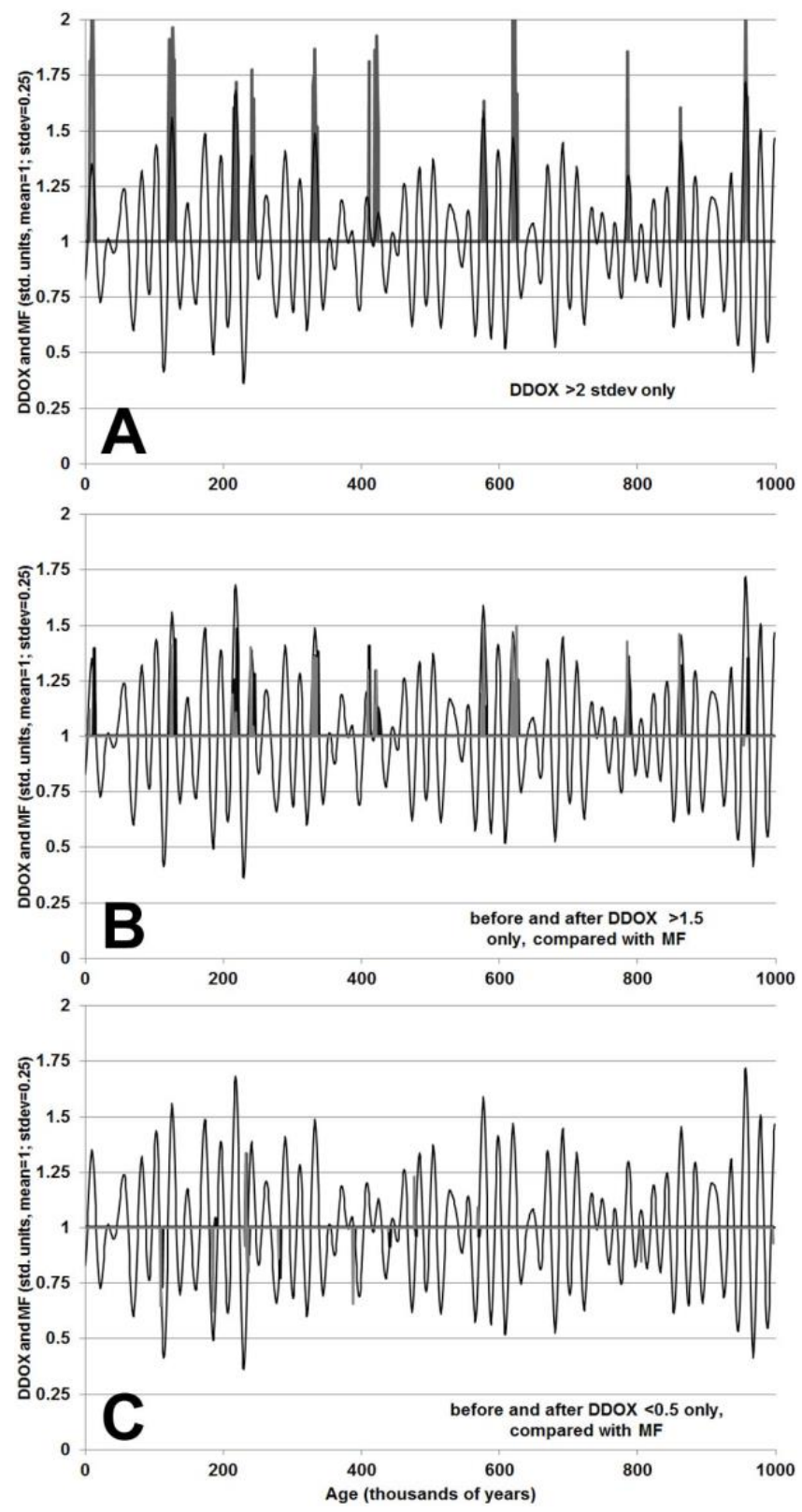

Fig. 6. Unusually large rates of change compared with MF. A, derivative of $\delta^{18} \mathrm{O}$ record (Table $\mathrm{A} 1 \mathrm{in} \mathrm{W}$. Berger, 2011) larger than 2 standard deviations above the mean, placed along the MF series (calculated by A.Berger and Loutre, 1991). These are the "terminations." $\mathbf{B}$, rates of change before and after events for which positive $\delta^{18} \mathrm{O}$ ' values exceed 2 standard deviations (search for persistence of fast positive rates). $\mathbf{C}$, rates of change before and after events for which negative $\delta^{18} \mathrm{O}^{\prime}$ values exceed 2 standard deviations (search for persistence) (mean of the series set to one, standard deviation to $0.25)$.
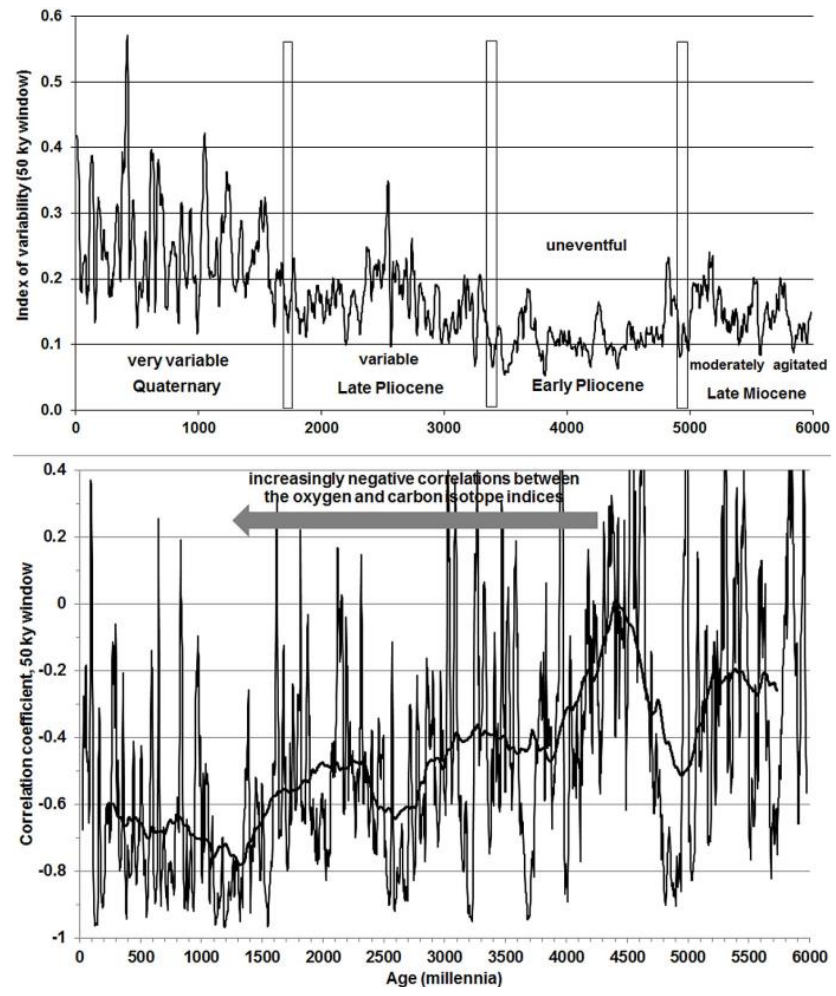

Fig. 7. The late Tertiary-to-Quaternary trend of increased variability (as seen in the oxygen isotopes) and the increased constraints on the carbon system (as seen in the evolution of correlation coefficients between oxygen and carbon isotopes). Data are from the compilation of Zachos et al. (2001), interpolated for $2 \mathrm{kyr}$ intervals. The correlation in the lower graph is based on a moving $50 \mathrm{kyr}$ window, with the solid line showing average conditions for $500 \mathrm{kyr}$.

rather rapidly. A system can enter a state of high agitation in response to unchanged forcing because of a high content of instability, which implies increased sensitivity to outside disturbance. In such a situation, forcing that "triggers" a response may be more important than forcing that gradually "drives" a system toward a new state. Any effects of a "trigger", of course, are inherently less predictable than those of a "driver". In this sense, it seems, the Quaternary, and especially the late Quaternary, is a less predictable environment than, say, the early Pliocene (Fig. 7). The change from predictable to unpredictable is of considerable interest in the context of evolution in the last $5 \mathrm{Myr}$, which presumably includes the invasion of the increasingly variable northern realm by migrating birds and various types of arctic mammals.

The overall trend toward increased agitation in the global climate system is not subtle at all, but is very evident. The trend is a result of a stepwise increase in variability, measured in terms of the changing standard deviation of the proxy parameter in a window (here: $50 \mathrm{kyr}$ ). The general increase in variability observed is presumably linked to the buildup of large ice masses in northern land areas. A step near $3 \mathrm{Ma}$ 
(million years ago) supports the concept (based on the discovery of glacial debris by drilling in the North Atlantic) that northern glacial ice masses (vulnerable to fast melting) date from roughly that time (Berggren, 1972; and many authors since). The moderately high agitation level at the end of the Miocene may owe to an earlier northern ice buildup (Jansen and Sjøholm, 1991; Larsen et al., 1994). If so, a decrease in agitation would be expected from northern warming, on a timescale of tens of thousands of years (as observed for the early Pliocene).

I suspect that increased heat transport by the Gulf Stream system was an important factor in northern warming, in consequence of closing the connection between the Caribbean and Pacific within the late Pliocene. Presumably, the northern ice buildup was not entirely prevented by the newly available heat, but was delayed for some time (W. Berger and Wefer, 1996). Eventually, northern ice appeared anyway, as the planet continued to cool. The increased supply of Gulf Stream heat, in the geologic time that followed, then helped make the northern ice masses unstable and vulnerable to sporadic removal. In this sense, the Quaternary may indeed owe some of its main features to the emergence of the Panama Isthmus, although not in the way envisaged by those who call on the additional heat to make vapor and snow.

It seems clear from inspection of Fig. 7 that the currently accepted boundaries between Miocene and Pliocene $(\sim 5 \mathrm{Ma})$, and between Pliocene and Pleistocene ( $\sim 1.8 \mathrm{Ma})$, are readily reconciled with the evidence for changes in climate variability. In addition, it is of interest that the general increase in climate variability parallels increasing participation of the carbon cycle in the climate narrative. The latter expresses itself as an increase in negative correlation (linear, windowed) between oxygen and carbon isotopes in the benthic deep-sea foraminifers, with a maximum (in negative correlation) near 1.3 Ma. The cause for the correlation is not known; it may reflect climate control on the buildup and destruction of forests, soil, or peat deposits on land, or highlatitude control on carbon content in the deep sea, or a combination of these processes, or factors involving the ocean.

Notably, there is no evidence, in these records, of a quiet time in the middle of the Pliocene. This relatively warm period (3 Myr to 3.3 Myr) has been studied for sensitivity to Milankovitch forcing (by climate modeling), and was found to likely have had substantial sea-level fluctuations around a mean that was substantially higher than today (Dolan et al., 2011).

\section{Conclusions}

The use of Milankovitch theory for the purpose of dating deep-sea sediments is an important and widespread practical application of the theory to deep-sea stratigraphy. Apparently, for the procedure to work, it is not necessary to understand how Milankovitch forcing is translated into changes in the climate system. However, a lack of understanding does negatively affect any use of ice-age history in drawing lessons for the climate problems of the present. The fact that understanding is very limited emerges from an inability to capture quantitatively the response of the global climate system to MF and any other forcing. An important problem is that the system responds as much to triggers as to drivers. Whenever MF provides the trigger it is not clear why the trigger was effective exactly at the time observed. Presumably the system is in a crucial state at that time; a state that is difficult or perhaps impossible to define using available proxies. As concerns the response of the climate system to drivers, it appears that this response is subject to unknown factors causing either enthusiastic or reluctant response.

Trends of increasing variability in climate response, when moving into the Quaternary, at the end of the late Tertiary, suggest that the buildup of large polar ice masses was responsible for the increased sensitivity of the system to disturbance, in agreement with the theory formulated by Milankovitch (1930). As the amplitudes of change became larger, the carbon cycle became increasingly involved as one element in the climatic variations.

Acknowledgements. I thank Didier Rousseau for asking me to write the essay, and I am indebted to two anonymous reviewers for cogent remarks with regard to the original draft of the manuscript.

Edited by: D. Fleitmann

\section{References}

Berger, A.: Pleistocene climate variability at astronomical frequencies, Quaternary Int., 2, 1-14, 1989.

Berger, A. and Loutre, M. F.: Insolation values for the climate of the last 10 million years, Quaternary Sci. Rev., 10, 297-317, 1991.

Berger, A. and Loutre, M. F.: Climate 400,000 years ago, a key to the future?, in: Earth's Climate and orbital Eccentricity, edited by: Droxler, A. W., Poore, R. Z., and Burckle, L. H., American Geophysical Union, Washington DC, 17-26, 2003.

Berger, A., Imbrie, J., Hays, J., Kukla, G., and Saltzman, B. (Eds.): Milankovitch and Climate: Understanding the Response to Astronomical Forcing: Dordrecht (D. Reidel), Vol. 2, 895 pp., 1984.

Berger, A., Schneider, S., and Duplessy, J. C. (Eds.): Climate and Geo-Sciences, A Challenge for Science and Society in the 21st Century, Kluwer Academic, Dordrecht, 724 pp., 1989.

Berger, A., Loutre, M. F., and Laskar, J.: Stability of the astronomical frequencies over the Earth's history for paleoclimate studies, Science, 255, 560-566, 1992.

Berger, A., Mélice, J. L., and Loutre, M. F.: On the origin of the 100-kyr cycles in the astronomical forcing, Paleoceanography, 20, PA4019, doi:10.1029/2005PA001173, 2005.

Berger, A. L., Gulick, S. P. S., Spotila, J. A., Upton, P., Jaeger, J. M., Chapman, J. B., Worthington, L. A., Pavlis, T. L., Ridgway, K. D., Willems, B. A., and and McAleer, R. J.: Quaternary tectonic response to intensified glacial erosion in an orogenic wedge, Nat. Geosci., 1, 793-799, doi:10.1038/ngeo334, 2008. 
Berger, W. H.: Experimenting with ice-age cycles in a spreadsheet, J. Geoscience Education, 45, 428-439, 1997.

Berger, W. H.: The 100-kyr ice-age cycle: internal oscillation or inclinational forcing?, Int. J. Earth Sci., 88, 305-316, 1999.

Berger, W. H.: Sea level in the Late Quaternary: Patterns of variation and implications, Int. J. Earth Sci., 97, 1143-1150, 2008.

Berger, W. H.: Geologist at sea: Aspects of ocean history, Ann. Reviews Marine Science, 3, 1-34, 2011.

Berger, W. H.: Milankovitch tuning of deep-sea records: Implications for maximum rates of change of sea level. Global Planet. Change, 101, 131-143, 2013.

Berger, W. H. and Wefer, G.: Klimageschichte aus Tiefseesedimenten - Neues vom Ontong-Java- Plateau (Westpazifik), Naturwissenschaften, 79, 541-550, 1992.

Berger, W. H. and Wefer, G.: Expeditions into the past: Paleoceanographic studies in the South Atlantic, in: The South Atlantic: Present and Past Circulation, edited by: Wefer, G., Berger, W. H., Siedler, G., and Webb, D. J., Springer-Verlag Berlin Heidelberg, 363-410, 1996.

Berger, W. H., Bickert, T., Schmidt, H., and Wefer, G.: Quaternary oxygen isotope record of pelagic foraminifers: Site 806, Ontong Java Plateau, Proceedings of the Ocean Drilling Program, Scientific Results, 130, 381-395, 1993.

Berggren, W. A.: Late Pliocene-Pleistocene glaciation, in: Init. Rept. DSDP, edited by: Laughton, A. and Berggren, W. A., Vol. 12, Washington DC, (US Govt. Printing Office), 953-963, 1972.

Brocklehurst, S. H.: A glacial driver of tectonics, Nat. Geosci., 1, 732-733, 2008.

Broecker, W. S. and Denton, G. H.: The role of ocean-atmosphere reorganizations in glacial cycles, Geochim. Cosmochim. Ac., 53, 2465-2501, 1989.

Broecker, W. S. and van Donk, J.: Insolation changes, ice volumes, and the O-18 record in deep-sea cores, Rev. Geophys. Space GE, 8, 169-198, 1970.

Champagnac, J.-D., Molnar, P., Sue, C., and Herman, F.: Tectonics, climate, and mountain topography, J. Geophys. Res., 117, B02403, doi:10.1029/2011JB008348, 2012.

Claussen, M., Fohlmeister, J., Ganopolski, A., and Brovkin, V.: Vegetation dynamics amplifies precessional forcing, Geophys. Res. Lett., 33, L09709, doi:10.1029/2006GL026111, 2006.

Dolan, A. M., Haywood, A. M., Hill, D. J., Dowsett, H. J., Hunter, S. J., Lunt, D. J., and Pickering, S. J.: Sensitivity of Pliocene ice sheets to orbital forcing, Palaeogeogr. Palaeocl., 309, 98-110, 2011.

Einsele, G., Ricken, W., and Seilacher, A. (Eds.): Cycles and Events in Stratigraphy, Springer Verlag, Berlin Heidelberg etc., 955 pp., 1991.

Elkibbi, M. and Rial, J. A.: An outsider's review of the astronomical theory of the climate: Is the eccentricity-driven insolation the main driver of the ice ages?, Earth. Sci. Rev., 56, 161-177, 2001.

Emiliani, C.: Pleistocene temperatures, J. Geol., 63, 538-578, 1955.

EPICA Community Members: Eight glacial cycles from an Antarctic ice core, Nature, 429, 623-628, 2004.

Fischer, A. G., Herbert, T. D., and Premoli-Silva, I.: Carbonate bedding cycles in Cretaceous pelagic and hemipelagic sediments, in: Fine-grained deposits and biofacies of the Cretaceous Western Interior Seaway: evidence of cyclic sedimentary processes, edited by: Pratt, L. M., Kauffman, E. G., and Zelt, F. B.,
Soc. Econ. Paleontol. Mineral, 2nd Annual Mid-year Meeting, Golden, Colorado, Field Trip Guide Book 4, 1-10, 1985.

Ganopolski, A. and Calov, R.: The role of orbital forcing, carbon dioxide and regolith in $100 \mathrm{kyr}$ glacial cycles, Clim. Past, 7, 1415-1425, doi:10.5194/cp-7-1415-2011, 2011.

Hays, J. D., Imbrie, J., and Shackleton, N. J.: Variations in the Earth's orbit: Pacemaker of the ice ages?, Science, 194, 1121$1132,1976$.

Hilgen, F. J., Krijgsman, W., Langereis, C. G., Lourens, L. J., Santarelli, A., and Zachariasse, W. J.: Extending the astronomical (polarity) timescale into the Miocene, Earth Planet. Sc. Lett., 136, 495-510, 1995.

Holden, P. B., Edwards, N. R., Wolf, E. W., Valdes, P. J., and Singarayer, J. S.: The Mid-Brunhes Event and West Antarctic ice sheet stability, J. Quaternary Sci., 26, 474-477, 2011.

Hughes, T.: Ice dynamics and deglaciation models when ice sheets collapsed, in: North America and Adjacent Oceans During the Last Deglaciation, edited by: Ruddiman, W. F. and Wright, H. E., The Geology of North America, v. K-3. Geol. Soc. America, Boulder, Colorado, 183-220, 1987.

Huybers, P.: Glacial variability over the last two million years: an extended depth-derived age model, continuous obliquity pacing, and the Pleistocene progression, Quaternary Sci. Rev., 26, 37-55, 2007.

Huybers, P.: Pleistocene glacial variability as a chaotic response to obliquity forcing, Clim. Past, 5, 481-488, doi:10.5194/cp-5-4812009, 2009.

Huybers, P.: Combined obliquity and precession pacing of late Pleistocene deglaciations, Nature, 480, 229-232, 2011.

Huybers, P. and Wunsch, C.: Obliquity pacing of the late Pleistocene glacial terminations, Nature, 434, 491-494, 2005.

Imbrie, J. and Imbrie, J. Z.: Modelling the climatic response to orbital variations, Science, 207, 943-953, 1980.

Imbrie, J., Hays, J. D., Martinson, D. G., McIntyre, A., Mix, A. C., Morley, J. J., Pisias, N. G., Prell, W. L., and Shackleton, N. J.: The orbital theory of Pleistocene climate: Support from a revised chronology of the marine $\delta^{18} \mathrm{O}$ record, in: Milankovitch and Climate (Part 1), edited by: Berger, A. L., Imbrie, J., Hays, J. D., Kukla, G., and Saltzman, B., 269-305, Hingham, Mass. (Reidel), 1984.

Imbrie, J., Boyle, E. A., Clemens, S. C., Duffy, A., Howard, W. R., Kukla, G., Kutzbach, J., Martinson, D. G., McIntyre, A., Mix, A. C., Molfino, B., Morley, J. J., Peterson, L. C., Pisias, N. G., Prell, W. L., Raymo, M. E., Shackleton, N. J., and Toggweiler, J. R.: On the structure and origin of major glaciation cycles 1 . Linear responses to Milankovitch forcing, Paleoceanography, 7, 701-738, 1992.

Imbrie, J., Berger, A., Boyle, E. A., Clemens, S. C., Duffy, A., Howard, W. R., Kukla, G., Kutzbach, J., Martinson, D. G., McIntyre, A., Mix, A. C., Molfino, B., Morley, J. J., Peterson, L. C., Pisias, N. G., Prell, W. L., Raymo, M. E., Shackleton, N. J., and Toggweiler, J. R.: On the structure and origin of major glaciation cycles 2 . The 100,000-year cycle, Paleoceanography, 8, 699$735,1993$.

Jansen, E. and Sjøholm, J.: Reconstruction of glaciation over the past 6 million years from ice-borne deposits in the Norwegian Sea, Nature, 349, 600-604, 1991.

Jansen, E., Overpeck, J., Briffa, K. R., Duplessy, J.-C., Joos, F., Masson-Delmotte, V., Olago, D., Otto-Bliesner, B., Peltier, W. 
R., Rahmstorf, S., Ramesh, R., Raynaud, D., Rind, D., Solomina, O., Villalba, R., and Zhang, D.: Palaeoclimate, in: Climate Change 2007: the Physical Science Basis; Contribution of Working Group I to the Fourth Assessment Report of the Intergovernmental Panel on Climate Change, edited by: Solomon, S., Qin, D., Manning, M., Chen, Z., Marquis, M., Averyt, K. B., Tignor, M., and Miller, H. L., Cambridge University Press, 433-497, 2007.

Kőppen, W. and Wegener, A.: Die Klimate der geologischen Vorzeit, Bornträger, Berlin, 256 pp., 1924.

Larsen, H. C., Saunders, A. D., Clift, P. D., Beget, J., Wei, W., Spezzaferri, S., and ODP 152 Scientific Party: Seven million years of glaciation in Greenland, Science, 264, 952-955, 1994.

Leuschner, D. C. and Sirocko, F.: Orbital insolation forcing of the Indian monsoon - a motor for climate changes?, Palaeogeogr. Palaeocli., 197, 83-95, 2003.

Liebrand, D., Lourens, L. J., Hodell, D. A., de Boer, B., van de Wal, R., Pälicke, H., and Gibbs, S. J.: Dynamics of 100-kyr glacial cycles during the early Miocene, Geophys. Res. Abstr., EGU2011-230-2.2011, EGU General Assembly 2011, Vienna, Austria, 2011.

Lisiecki, L. L.: Links between eccentrity forcing and the 100,000-year glacial cycle, Nat. Geosci., 2, 349-352, doi:10.1038/ngeo828, 2010.

Lisiecki, L. E. and Raymo, M. E.: A Pliocene-Pleistocene stack of 57 globally distributed benthic $\delta^{18} \mathrm{O}$ records, Paleoceanography, 20, PA1003, doi:10.1029/2004PA001071, 2005.

Liu, H. L. and Chao, B. F.: Wavelet spectral analysis of the Earth's orbital variations and paleoclimatic cycles, J. Atmos. Sci., 55, 227-236, 1998.

Maslin, M. A. and Ridgwell, A.: Mid-Pleistocene Revolution and the eccentricity myth, Special Publication of the Geological Society of London 247, 19-34, 2005.

Meyers, S. R., Sageman, B. B., and Pagani, M.: Resolving Milankovitch: Consideration of signal and noise, Am. J. Sci., 308, 770-786, 2008.

Milankovitch, M.: Mathematische Klimalehre und astronomische Theorie der Klimaschwankungen, in: Handbuch der Klimatologie, edited by: Köppen, W. and Geiger, R., Vol. 1, Gebrüder Bornträger, Berlin, 1-176, 1930.

Mudelsee, M. and Schulz, M.: The mid-Pleistocene climate transition: onset of $100 \mathrm{ka}$ cycle lags ice volume build-up by $280 \mathrm{ka}$, Earth Planet. Sci. Lett., 151, 117-123, 1997.

Mudelsee, M. and Stattegger, K.: Exploring the structure of the midPleistocene revolution with advanced methods of time-series analysis, Geologische Rundschau, 86, 499-511, 1997.

Muller, R. A. and MacDonald, G. J.: Ice Ages and Astronomical Causes: Data, Spectral Analysis, and Mechanisms, SpringerPraxis, London, 318 pp., 2000.
Nie, J.: Coupled 100-kyr cycles between 3 and 1 Ma in terrestrial and marine paleoclimatic records, Geochem. Geophy. Geosy., 12, Q10Z32, doi:10.1029/2011GC003772, 2011.

Paillard, D. and Parrenin, F.: The Antarctic ice sheet and the triggering of deglaciation, Earth Planet. Sci. Lett., 227, 203-271, 2004.

Paul, A. and Berger, W. H.: Modellierung der Eiszeiten: Klimazyklen und Klimasprünge, Geowissenschaften, 15, 20-27, 1997.

Pisias, N. G. and Moore, T. C.: The evolution of Pleistocene climate: a time series approach, Earth Planet Sc. Lett., 52, 450-456, 1981.

Pollard, D.: Some ice-age aspects of calving ice-sheet model, in: Milankovitch and Climate, Part 2, edited by: Berger, A. L., Imbrie, J., Hays, J. D., Kukla, G., and Saltzman, B., 541-564, D. Reidel, Dordrecht, 1984.

Raymo, M. E. and Nisancioglu, K. H.: The 41 kyr world: Milankovitch's other unsolved mystery, Paleoceanography, 18, 111-11-6, 2003.

Raymo, M. E., Lisiecki, L. E., and Nisancioglu, K. H. PlioPleistocene ice volume, Antarctic climate, and the global $\delta 18 \mathrm{O}$ record, Science, 313, 492-495, 2006.

Ridgwell, A., Watson, A., and Raymo, M.: Is the spectral signature of the 100-kyr glacial cycle consistent with a Milankovitch origin?, Paleoceanography, 14, 437-440, 1999.

Roe, G. H. and Baker, M. B.: Why is climate sensitivity so unpredictable?, Science, 318, 629-632, 2007.

Ruddiman, W. F., Raymo, M. E., Martinson, D. G., Clement, B. M., and Backman, J.: Mid-Pleistocene evolution of Northern Hemisphere climate, Paleoceanography, 4, 353-412, 1989.

Schwarzacher, W.: Cyclostratigraphy and the Milankovitch Theory, Elsevier Amsterdam London etc., 225 pp., 1993.

Shackleton, N. J., Berger, A., and Peltier, W. R.: An alternative astronomical calibration of the lower Pleistocene timescale based on ODP Site 677, T. RSE Earth, 81, 251-261, 1990.

Shackleton, N. J., Crowhurst, S., Hagelberg, T., Pisias, N. G., and Schneider, D. A.: A new late Neogene time scale: Application to Leg 138 sites, Proc. Ocean Drill. Program Sci. Results, 138, 73-101, 1995.

Tomkin, J. H. and Roe, G. H.: Climate and tectonic controls on glaciated critical taper-orogens, Earth Planet. Sc. Lett., 262, 385397, 2007.

Tziperman, E., Raymo, M. E., Huybers, P., and Wunsch, C.: Consequences of pacing the Pleistocene $100 \mathrm{kyr}$ ice ages by nonlinear phase locking to Milankovitch forcing, Paleoceanography, 21, PA4206, doi:10.1029/2005PA001241, 2006.

Zachos, J., Pagani, M., Sloan, L., Thomas, E., and Billups, K.: Trends, rhythms, and aberrations in global climate $65 \mathrm{Ma}$ to present, Science, 292, 686-693, 2001. 